\title{
Prospects for the Use of Gondola Cars on Bogies of Model ZK1 in the Organization of Heavy Freight Traffic in the Republic of Kazakhstan
}

\author{
Gulnar IMASHEVA*, Seidulla ABDULLAYEV**, Natalya TOKMURZINA***, \\ Nazdana ADILOVA****, Gabit BAKYT****** \\ *Academy of civil aviation, Zakarpatskaya 44, 050039 Almaty, Kazakhstan, E-mail: seidulla@mail.ru \\ **Kazakh Academy of Transport and Communications named after M. Tynyshpayev, Shevchenko 97, 050012 Almaty, \\ Kazakhstan, E-mail: seidulla@mail.ru (corresponding author) \\ ***Kazakh Academy of Transport and Communications named after M. Tynyshpayev, Shevchenko 97, 050012 Almaty, \\ Kazakhstan,E-mail: natalytokmur@mail.ru \\ ****Kazakh Academy of Transport and Communications named after M. Tynyshpayev, Shevchenko 97, 050012 Almaty, \\ Kazakhstan, E-mail: adilova_n@mail.ru \\ *****Kazakh Academy of Transport and Communications named after M. Tynyshpayev, Shevchenko 97, 050012 Almaty, \\ Kazakhstan, E-mail: gaba_b@bk.ru
}

crossref http://dx.doi.org/10.5755/j01.mech.24.1.17710

\section{Introduction}

The introduction of heavy freight trains is a complex task, associated with the use of more powerful locomotives, higher axle loads, reconstruction of road infrastructure and electricity supply, improvement of technology of transportation process [1-3]. The use of heavy freight trains will reduce the fleet of electric locomotives for a specified turnover and increase throughput plots [4-6].

In several foreign countries, including the USA and Canada the use of heavy freight trains is reduced operating costs due to the reduction of locomotive brigades, which consequently reduced the price of the carriage of goods $[1,6,7]$.

Development strategy of JSC "national company "Kazakhstan Temir Zholy" (hereinafter - JSC "NC "KTZ") until 2020 provides for the introduction of innovative systems of planning, organization and implementation of transportations, fundamentally improve the efficiency of use of rolling stock and the capacity of sites of the network.

The most promising to enter the heavy freight traffic in Kazakhstan are the areas of delivery of coal from Ekibastuz routes Ekibastuz - Petropavlovsk; Ekibastuz - Karaganda; Ekibastuz - Zolotaya Sopka (Russian Federation).

In implementing this strategy, the Company seeks to raise the average weight of trains by $30 \%$. Currently, standardized weight norm of freight trains in the Republic of Kazakhstan does not exceed 6000 tons.

On these plots the mass of freight trains is limited by train length by condition free installation on station tracks (the maximum number of wagons - 71 conventional car), which corresponds to the length of receiving-departure tracks is equal to $1050 \mathrm{~m}$.

Increase the weight standards of freight trains without reconstruction of infrastructure possible in the operation of freight cars with axle load of $245 \mathrm{kN}$, which will increase the weight of freight trains up to 7100 tons [8-10].

Thus, the purpose of this article is the analysis of the construction trucks wagons models 12-9941 produced by LLP "Kazakhstan wagon company".

\section{Analysis of fleet of freight wagons}

Freight car fleet of the Company is 65521 units. The major share of the car fleet are gondolas 49.8 per cent. Other types of cars in car Park are as follows: indoor $15,2 \%$, the platform $-5,1 \%$, tanks and $9.9 \%$, other $-20,0 \%$ [11]. The adopted axial loading of freight cars is not more than $230 \mathrm{kN}$.

With the 60-ies of XX century in the United States, Canada, Australia and other countries produced four-axle wagons with a capacity of 90 tons (axial load of about $294 \mathrm{kN}$ ) and exploiting the car Park with loads of up to $340 \mathrm{kN}$ in trains weighing $12-20$ thousand tons. Foreign manufacturers widely used aluminum alloys for the manufacture of bodies of freight cars, which allows significantly reducing the tare weight of the car to $17-23$ tons with load ratings $117-120$ tons.

For comparison, the freight wagons of $1520 \mathrm{~mm}$ have a relatively low capacity (60-70 tons), require additional costs associated with loading-unloading and securing of cargo have a small turnaround and a low level of specialization, the axial load is $230 \mathrm{kN}$ tare weight is $240 \mathrm{kN}$.

Due to the frequent failures of components and parts of freight cars, the most massive of which are the fractures of cast parts of bogies of the model 18-100, widely used on the Railways of $1520 \mathrm{~mm}$ of the States-participants of the Commonwealth of Independent States, is steadily increasing cases of derailment of trains, resulting in significant financial losses.

Design and manufacturing technology of the model developed in 40-50-ies of the last century. Recently, the fractures are more often seen on the side frames of the trucks that were in operation three years or less, which indicates poor quality of their manufacture, do not provide guaranteed lifetime [12].

\section{Design features of the trucks of model ZK1}

In 2012, LLP "Kazakhstan car-building company" has mastered the production of gondola cars of model 129941 with improved technical and economic characteristics. 
Gondola cars of model 12-9941 are made by the project of Qiqihar railway company (PRC) with the use of trucks of model ZK1.

Trucks of model ZK1 compared with conventional three-piece freight trucks have a number of design features. Truck model ZK1 is designed for an axial load of $245 \mathrm{kN}$ and a speed of $120 \mathrm{~km} / \mathrm{h}$.

Freight two-axle three-piece truck ZK1 produced in China is made by the standards of TB/T2942 (Fig. 1) [13]. It consists of a cast truck bolster of a closed box section with four technological openings and cast side frames with process windows.

For a more rigid connection between the side frames, bolster beam and spring sets, the side frames are diagonally interconnected by means of two cross-bonded elastic elements (anchor). They go through technological openings of the truck bolster, the technological window of the side frames and are fixed in technological boxes of side frames using four control arms.

The design articulation of a truck bolster with the side frames ensures the squareness of the shape of the bogie. The benefit is the alignment of wheelset axles when the truck traffic.

For ease of fit in the curves of the track sections, these carts have $11 \mathrm{~mm}$ transverse stroke of the wheel pair relative to the sidewall. To reduce the yaw of the truck slipping in the nodes of the applied rubber adapters. The center of rigidity shear is achieved the diagonals of the axlebox housing with the help of anchor links. In addition, the bogie of model ZK1 is equipped with wear-resistant liner between the center plate and thrust bearing, elastic-roller bearers of constant contact, a wedge in the central absorber suspension $[8,14,15]$.

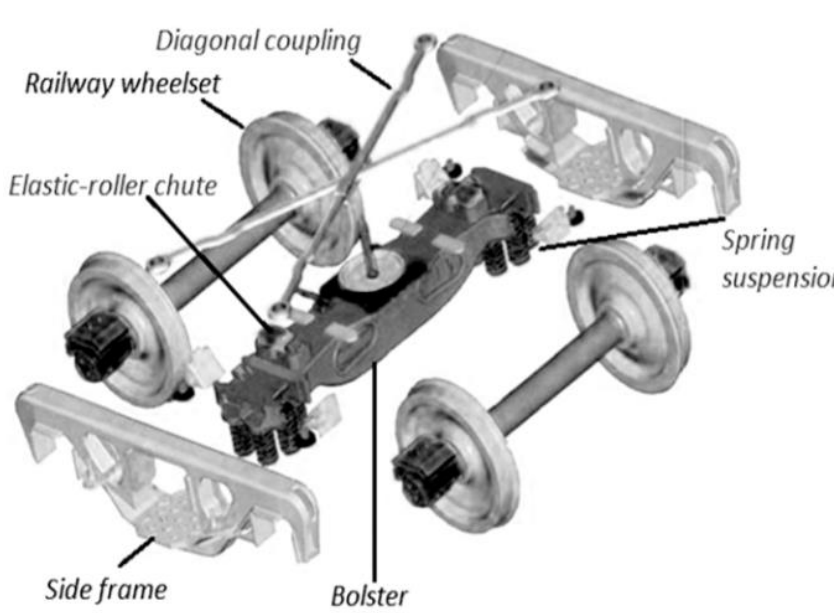

a

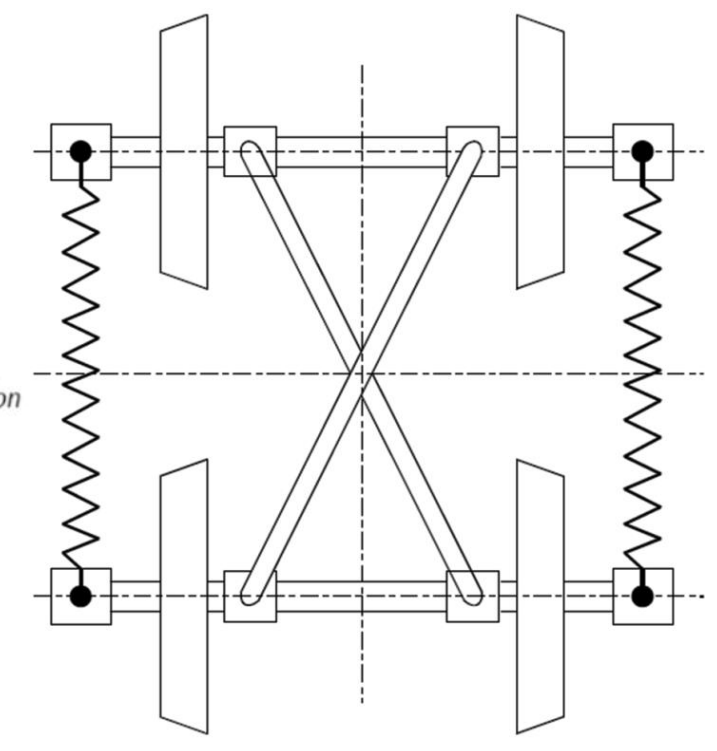

b

Fig. 1 ZK1 model bogie: general structure (a), scheme (b)

Analysis and design of the truck revealed that the design of the cargo trucks of model ZK1 excludes:

- rushing longitudinal side frames relative to each other (truck 18-100 they reach $15-20 \mathrm{~mm}$ ), resulting in a decrease in the intensity of the wagging of the truck, improves the smoothness of the car;

- pendulum oscillation of the frames about their own longitudinal axes, the result is uniform transfer of loads on the elements of the axle unit, which eliminates the distortions of the bearings.

In addition, the comparison of cars with 18-100 bogies of freight cars on bogies model ZK1 have a higher design speed, less wear of wheels and more time between repairs [13].

\section{The dynamic characteristics of gondola cars on bogies of the model ZK1 and indicators of their impact on railway track}

By order of JSC "NC "KTZ" Testing laboratory of rolling stock, Dnipropetrovsk national University of railway transport in 2011, conducted the certification testing of the batch of gondola cars model 12-9941. During the certification testing of these gondolas were the main dynamic characteristics, given in Table 1 [16].

Analysis of the data table. 1 shows that the dynamic characteristics of the cars meet the requirements of the international standard [17].

The effects of ZK1 bogies on the path determined by calculation.

Calculation of stresses in structural elements of the path produced by the formulas given in $[10,18]$.

The maximum stresses in the elements of track structure under the action of the truck ZK1 was calculated by the formulas:

- bending stresses of vertical load in the rail flange:

$$
\sigma_{p}=f \frac{P^{\max }+\sum \mu_{i} P_{i}}{4 k W} \leq\left[\sigma_{p}\right], \mathrm{MPa}
$$

- stresses in ballast under each sleeper:

$$
\sigma_{b}=\frac{k l_{p m}}{2 \Omega_{\alpha}}\left(P^{\max }+\sum \eta_{i} P_{i}\right) \leq\left[\sigma_{b}\right], \mathrm{MPa}
$$


here: $M$ is bending moment, $\mathrm{Nm} ; W$ is strength moment of rail cross section in respect of flange, $\mathrm{m}^{3} ; \mathrm{P}_{i}$ is vertical dynamic load on rail from rated wheel, $\mathrm{N} ; \mu_{i}$ and $\eta_{i}$ are coefficients, evaluating influence of contiguous (not rated) axes (bending moment is proportional to the influence line $\mu$ and load to sleeper; elastic deflection will influence line $\eta) ; P^{\max }$ is vertical dynamic load on rail from rated wheel, $\mathrm{N} ; k$ is coefficient of rail and rail flange relative stiffness, calculated according to formula, $\mathrm{m}^{-1} ; f$ is coefficient, evaluating eccentricity of acting forces; $l_{p . m}$. is distance between axes of sleepers, $\mathrm{m} ; \omega$ - is fish plate area, $\mathrm{m}^{2} ; \Omega_{\alpha}$ area of supporting half-sleeper, $\mathrm{m}^{2} ;\left\lfloor\sigma_{p}\right\rfloor,\left\lfloor\sigma_{p . m .}\right\rfloor,\left[\sigma_{b}\right]$ are permissible values of corresponding stresses. Permissible values differ in various sources $[9,19,20]$.

Table 1

The main characteristics of Gondola cars on bogies of the model ZK1

\begin{tabular}{|l|c|}
\hline \multicolumn{1}{|c|}{ Indicator } & Value \\
\hline Carrying capacity, tons & 75 \\
\hline $\begin{array}{l}\text { The maximum design load from wheel pair on } \\
\text { rails, kN }\end{array}$ & 245 \\
\hline Design speed, km/h & 120 \\
\hline Carriage base, mm & 1900 \\
\hline $\begin{array}{l}\text { The mass of one cart assembly is not more than, } \\
\text { kg }\end{array}$ & 5300 \\
\hline $\begin{array}{l}\text { Static deflection of spring suspension truck with a } \\
\text { maximum load from wheelset on rail, mm }\end{array}$ & 65 \\
\hline Frame strength is not more than, kN & 93 \\
\hline $\begin{array}{l}\text { The coefficient of structural margin of deflection } \\
\text { for suspension at the maximum load from wheel } \\
\text { set on rail }\end{array}$ & 1,8 \\
\hline $\begin{array}{l}\text { The coefficient of stability from the wheels derail- } \\
\text { ment }\end{array}$ & 1,6 \\
\hline $\begin{array}{l}\text { The coefficient of lateral stability of the carriage } \\
\text { from tipping over while moving in the curved } \\
\text { track }\end{array}$ & 2,0 \\
\hline $\begin{array}{l}\text { The coefficient of vertical dynamics of the body } \\
\text { at maximum load from wheel set on rail }\end{array}$ & 0,48 \\
\hline $\begin{array}{l}\text { The coefficient of vertical dynamics of a bogie } \\
\text { frame at maximum load from wheel set on rail }\end{array}$ & 0,68 \\
\hline The vertical acceleration of the body & $0,39 \mathrm{~g}$ \\
\hline The horizontal acceleration of the body & $0,22 \mathrm{~g}$ \\
\hline
\end{tabular}

Calculation of stresses in the elements of track structure under the action of the truck ZK1 в straight parts of the road were produced for rails of type R65, wooden and concrete sleepers by the number 2000 and 1840 units per $1 \mathrm{~km}$, crushed stone ballast.

In Figs. $2-4$ shows the stresses in the elements of track structure for type R65 rails, concrete sleepers quantity of 2000 units per $1 \mathrm{~km}$, crushed stone ballast. The modulus of elasticity of rails base was taken equal to $U=150 \mathrm{MPa}$ and $U=100 \mathrm{MPa}$.

In Figs. $5-7$ shows the stresses in the elements of track structure for type R65 rails, on wooden ties by the number 2000 and 1840 units per $1 \mathrm{~km}$ of crushed stone ballast.

The analysis of Figs. $2-7$ have shown that the stresses in the design of the track structure under the action of the truck ZK1 does not exceed the permissible limits in both straight and curve track sections.
As can be seen from Figs. 2-7, the stress-strain state of structural elements of the path is influenced by the modulus of elasticity of rails base, the speed and the radius of the curve sections of track.

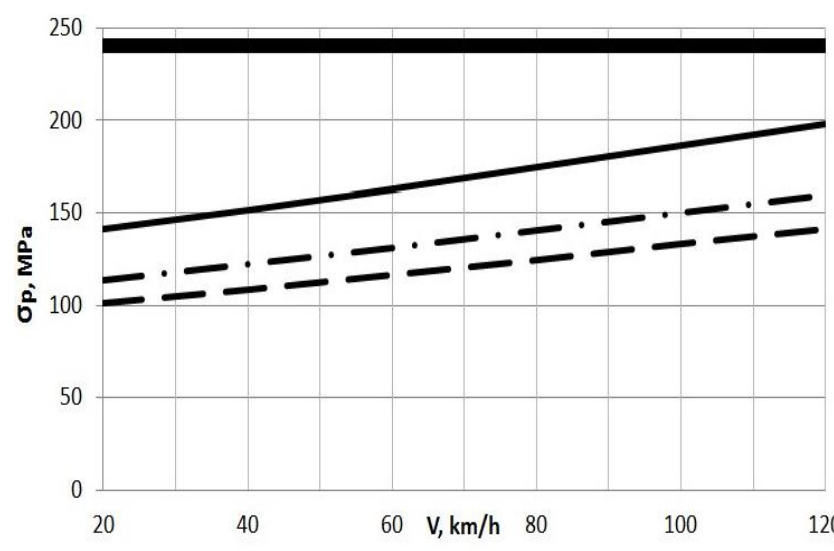

a

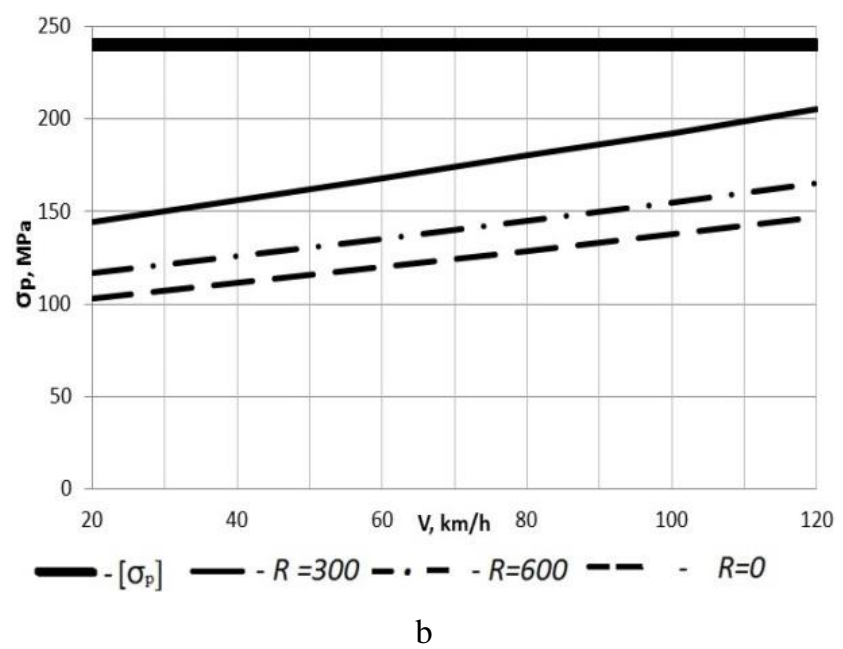

Fig. 2 Stress in the edges of rail foot in tangent $(R=0 \mathrm{~m})$ and curved track $(R=600 \mathrm{~m}, R=300 \mathrm{~m})$ for rails $\mathrm{R} 65$, ballast - crushed stone, concrete sleepers - 2000 pieces per $1 \mathrm{~km}$, the modulus of elasticity of rails base: $U=150 \mathrm{MPa}(\mathrm{a}), U=100 \mathrm{MPa}$ (b)

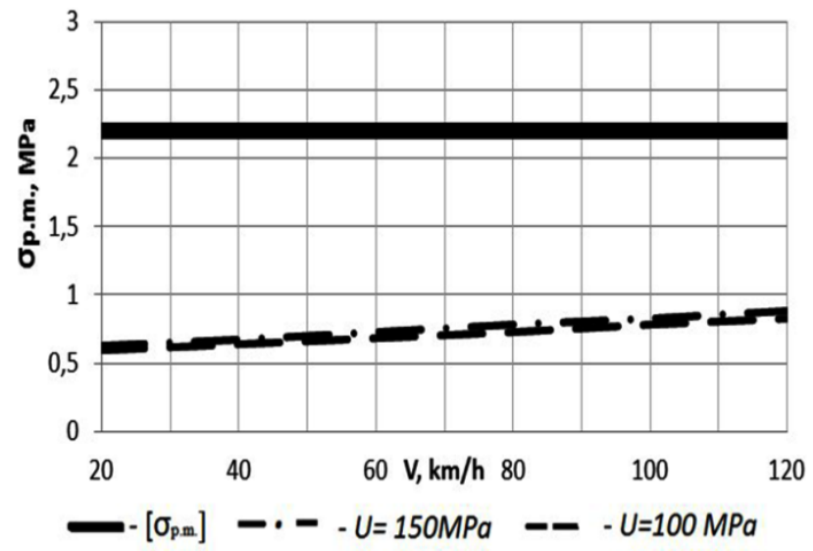

Fig. 3 Stress under rail bearing plates for rails R65, ballast crushed stone, concrete sleepers - 2000 pieces per $1 \mathrm{~km}$ 


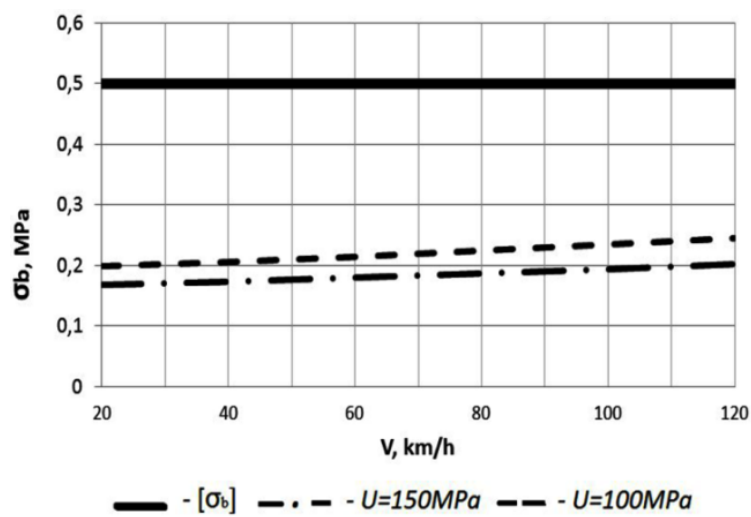

Fig. 4 Stress in ballast layer under cross-tiles for rails R65, ballast - crushed stone, concrete sleepers - 2000 pieces per $1 \mathrm{~km}$

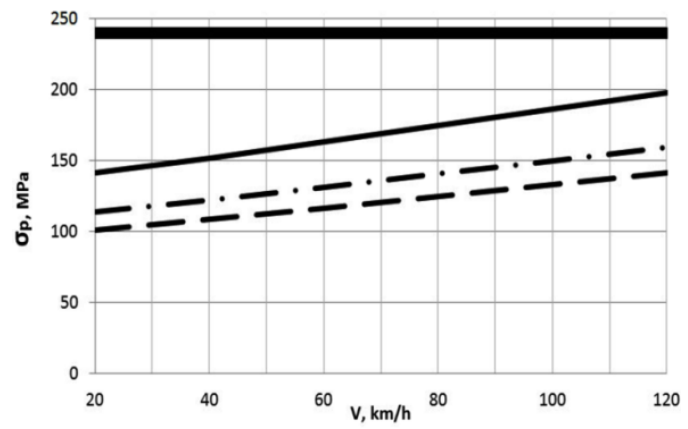

a

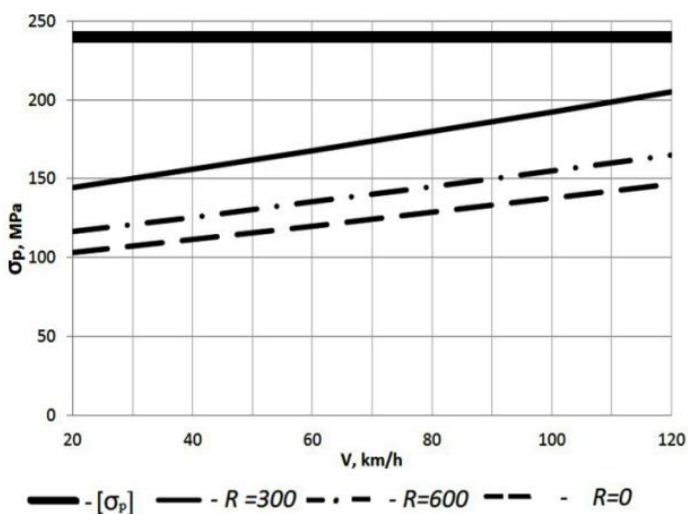

b

Fig. 5 Stress in the edges of rail foot in tangent $(R=0 \mathrm{~m})$ and curved sections of track $(R=600 \mathrm{~m}, R=300 \mathrm{~m})$ for rails R65, ballast - crushed stone, the modulus of elasticity of rails base $U=29 \mathrm{MPa}$, wooden sleepers: 2000 pieces per $1 \mathrm{~km} \mathrm{(a),} 1840$ pieces per $1 \mathrm{~km}$ (b)

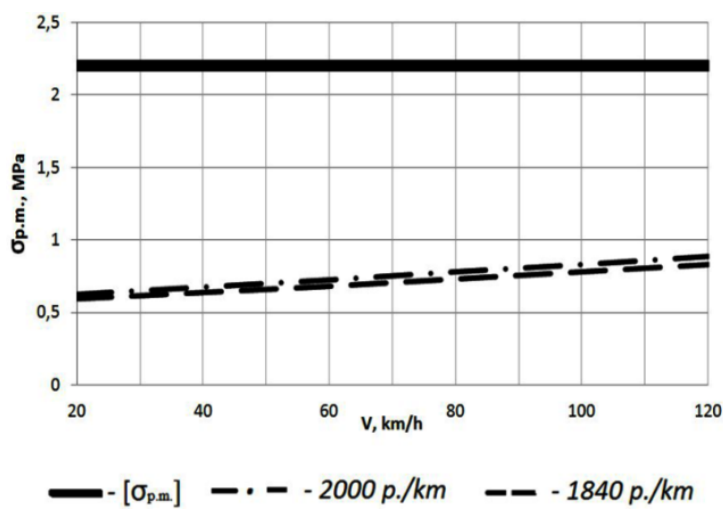

Fig. 6 Stress under rail bearing plates for rails R65, ballast - crushed stone, wooden sleepers

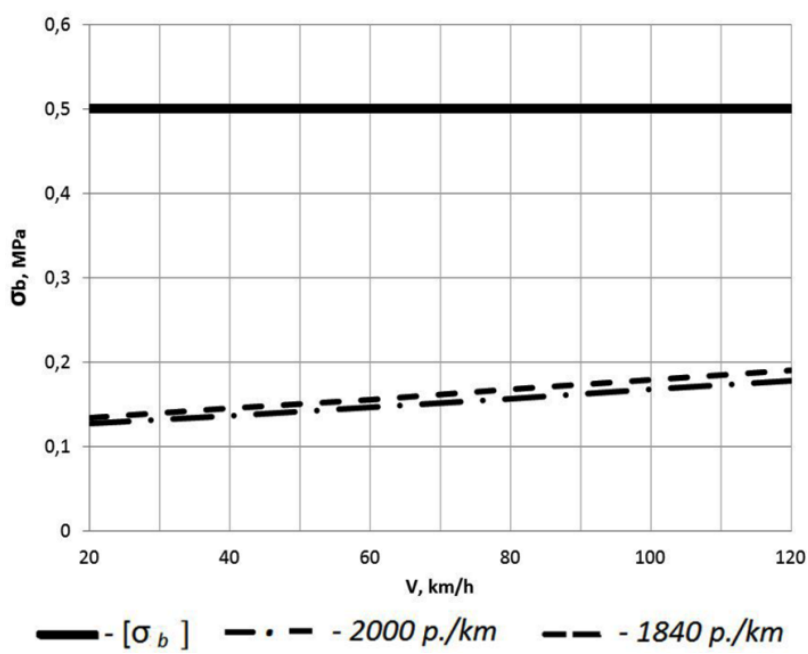

Fig. 7 Stress in ballast layer under rails for rails R65, ballast - crushed stone, wooden sleepers

\section{Conclusions}

1. Application in areas Ekibastuz - Petropavlovsk; Ekibastuz - Karaganda; Ekibastuz - Golden Hill of gondola wagons of model 12-9941 with axle load of $245 \mathrm{kN}$ will increase the weight norm of freight trains by 16 percent without the reconstruction of the rail track and increasing the length of station tracks.

2. For the considered structures of track structure:

- the maximum stress in the edge of the foot rail from the impact of truck ZK1 does not exceed $150 \mathrm{MPa}$ in the straight parts of the road and $210 \mathrm{MPa}$ in the curved track;

- maximum voltage under the linings of the sleepers is less than $1 \mathrm{MPa}$;

- the maximum stress in the ballast layer under the sleeper does not exceed 0.25 MPa.

3. Analysis of the stress state of the standard design path showed that the estimated parameters of stresses in the structural elements of the route are not exceeded in straight and curved track, when exposed to the path of the truck $\mathrm{ZK} 1$, moving at speeds up to $120 \mathrm{~km} / \mathrm{h}$ inclusive.

Thus, the considered designs of gondola wagons of models 12-9941 can be used for cargo transportation without the necessity of modernization of the railway, which will give an opportunity to increase traffic without significant financial costs.

\section{References}

1. Spiryagin, M.; Wolfs, P.; Cole, C.; Spiryagin, V.; Sun, Y.Q.; McSweeney, T. 2016. Design and simulation of heavy haul locomotives and trains, London: CRC Press.

https://doi.org/10.1201/9781315369792.

2. McCallen, R.; Browand, F.; Ross, J. 2013. The aerodynamics of heavy vehicles: trucks, buses, and trains, Berlin: Springer-Verlag.

3. Dudin, M.N.; Frolova, E.E.; Kuznetsov, M.N.; Drobysheva, L.V.; Krasulya, E.V. 2016. Green Logistics as an Instrument for Putting Together a New Model for Professional and Career-Broadening Training in Global Economic Space, International Journal of Environmental and Science Education 11(15): 8693-8705. 
4. Xie, T.; Hu, J.; Peng, Z.; Liu, Ch. 2015. Synthesis of seven-speed planetary gear trains for heavy-duty commercial vehicle, Mechanism and Machine Theory 90: 230-239.

http://dx.doi.org/10.1016/j.mechmachtheory.2014.12.012.

5. Wu, Q.; Cole, C.R.; Spiryagin, M. 2016. A method to improve draft gear designs for heavy haul trains, Australia: Engineers Australia.

6. Xu, Z.Q.; Ma, W.H.; Wu, Q.; Luo, S.H. 2013. Coupler rotation behavior and its effect on heavy haul trains. Vehicle system dynamics 51(12): 1818-1838. http://dx.doi.org/10.1080/00423114.2013.834369.

7. Wu, Q.; Luo, S.; Cole, C. 2014. Longitudinal dynamics and energy analysis for heavy haul trains, Journal of Modern Transportation 22(3): 127-136. http://dx.doi.org/10.1007/s40534-014-0055-x.

8. Boronenko, Yu.; Orlova, A.; Rudakova, E. 2006. Influence of construction schemes and parameters of three-piece freight bogies on wagon stability, ride and curving qualities, Vehicle System Dynamics 44: 402414.

http://dx.doi.org/10.1080/00423110600872341.

9. Methods of assessing the impact of rolling stock on the path by the condition of reliability, approved by order of the Vice-President of JSC "NC "KTZ" of 15 June 2004 , No. CPU-52/14/189/04.

10. Gailiene, I.; Podagelis, I. 2008. Evaluation of the track superstructure of lithunian railway lines calculating characteristics of strength, In Proceedings of the $7^{\text {th }}$ International Conference «Environmental engineering». Vilnius Gediminas Technical University, pp. 11461153.

11. The strategy of innovation-technological development of the group of companies of JSC "National company "Kazakhstan Temir Zholy" for the period 2013 - 2018. (Protocol No. 13).

12. Orlova, A.; Boronenko, Yu. 2006. The anatomy of railway vehicle running gear, London: CRC Press.

13. Karibzhanov, E.A. 2009. Freight wagons in Kazakhstan: improving technical condition, Cars and car economy 4(20): 34-36.

14. Blokhin, E.P.; Alpysbaev, K.T. 2012. ZK1 bogie wagons built in China, Car fleet 9(66): 12-14.

15. Beach, V. 2001. International Heavy Haul Association, Guidelines to Best Practices for Heavy Haul Railway Operations: Wheel and Rail Interface Issues.

16. Protocol of certification tests № 10-11/ILPS 22.12.2011. Testing laboratory of rolling stock, Dnipropetrovsk national University of railway transport.

17. GOST 33211-2014. 2014. Cars. Requirements for strength and dynamic properties, Moscow: Interstate Council for Standardization, Metrology and Certification.

18. Guramishvili, G.; Moistsrapishvili, M.;

Andghuladze, L. 2014. Features of Rail Strength Analysis in Conditions of Increased Force Loading, International Scholarly and Scientific Research \& Innovation 8(5): 319-323

19. Stoyanovich, G.M. 2013. Calculations of the permanent way of strength and resistance: a course of lectures, Khabarovsk: Far Eastern State Transport University press.

20. GOST R 55050-2012. 2012. Railway rolling stock. Norms of permissible impact on railway track and testing methods.

G. Imasheva, S. Abdullayev, N. Tokmurzina, N. Adilova, G. Bakyt

\section{PROSPECTS FOR THE USE OF GONDOLA CARS ON BOGIES OF MODEL ZK1 IN THE ORGANIZATION OF HEAVY FREIGHT TRAFFIC IN THE REPUBLIC OF KAZAKHSTAN}

S u m m a r y

The increase in heavy freight traffic in recent years is fueled by an increase in demand for coal as an alternative energy resource of oil, and also steel, in the manufacture of which large quantities of iron ore are required. However, in the former Soviet Union, the use of heavy freight trains was complicated due to insufficient quality of the railway. In this regard, the article considers the features of construction truck wagons of models 12-9941 produced by LLP "Kazakhstan car-building company" according to the project of Qiqihar railway company (PRC). The laboratory testing of rolling stock conducted in Dnipropetrovsk national University of railway transport has identified the main dynamic characteristics that meet the requirements of the international standard. The use of gondola wagons of model 129941 in the organization of the heavy traffic creates tensions in the construction of the permanent way, which do not exceed the permissible limits in both straight and curve track sections.

Keywords: dynamic characteristics of truck wagons, freight wagons, heavy freight trains, railway, truck wagons.

Received March 07, 2017 Accepted February 15, 2018 